\title{
SOSYAL MEDYADA TERÖR PROPAGANDASI: DEAŞ ÖRNEĞi
}

\section{Erdem Taşdemir ${ }^{1}$}

\begin{abstract}
ÖZ
Le Bon'un da ifade ettiği gibi "Toplumların şuursuz hareketlerinin, kişilerin şuurlu faaliyetleri yerine geçmesi çağımızın başlıca zaaflarındandır". Bu şuursuz eylemler, kişileri terör örgütlerinin sempatizanı yaparak radikal görüşlerin artmasına neden olmuştur. Günümüzde terör örgütleri amaçlarına ulaşmak maksadıyla planlı ve sistematik bir şekilde propaganda faaliyetleri yürütmektedirler. Kontrol altında tutmanın zor olduğu, denetim mekanizmalarının yetersiz kaldığı ve her geçen gün etkin bir büyüme gösteren sosyal ağlar sayesinde bu örgütler etkili propaganda imkanı yakalamaktadırlar. Bu çalışma, propaganda faaliyetlerini tarihsel bakış açısıyla anlamaya çalışırken yeni bir eğilim olan sosyal medya propagandasını DEAŞ örneği üzerinden açıklamayı hedeflemektedir. $\mathrm{Bu}$ terör örgütünün sosyal medya stratejileri analiz edilerek kullandığı mecralar ile hedef ve amaçları ortaya konulmuştur. Çalışma ile sosyal medya üzerinden gerçekleştirilen terör amaçlı propaganda faaliyetlerinin toplumsal yansımaları, mevcut durum, Türkiye özelinde yürütülen mücadele, alınan önlemler ve hukuki düzenlemeler yorumlanarak birtakım öneriler dizisi sunulmaktadır.
\end{abstract}

Anahtar Kelimeler: Propaganda, Sosyal Medya, Terör, DEAŞ

\section{TERROR PROPAGANDA ON SOCIAL MEDIA: DEAS}

\begin{abstract}
As Le Bon states, "Replacing people's conscious actions with unconscious movements is the main weakness of our age". These unconscious actions caused the increcement of radical views by making people sympathizers of terrorist organizations. Today terrorist organizations are conducting planned and systematic propaganda with the intention of reaching their goals. Since the supervision mechanisms are insufficient and the control is difficult, thanks to social networks, which show active growth every each day, the organizations find opportunity for effective propaganda. This study aims to explain the social media propaganda-as a new tendency, by the example of DEAŞ, while trying to understand the propaganda activities from a historical point of view. By analyzing the social media strategies of this organization, their aims and purposes are revealed through the channels they use. With this work a set of suggestions are offered by interpreting the social reflection of terror-based propagandas which are conducted via social media; the current condition, the Turkey-specific tackling; the precautions taken and legal arrangements.
\end{abstract}

Keywords: Propaganda, Social Media, Terror, DEAŞ

\footnotetext{
${ }^{1}$ Doç. Dr. Karadeniz Teknik Üniversitesi, İletişim Fakültesi, tasdemir@ktu.edu.tr
} 


\section{Giriş}

Günümüzde terör örgütleri ile yapılan mücadele sadece savaş alanında değil çok boyutlu olarak gerçekleştirilmek durumundadır. İnsan hayatını kolaylaştırmak, iletişim ortamını geliştirmek ve genişletmek için ortaya çıkan yeni iletişim araçlarından biri olan sosyal medya, devletler ile terör örgütleri arasında yeni bir mücadele alanı olarak ortaya çıkmaktadır. Sosyal medyanın büyük bir kitle tarafından kullanılması ve denetim güçlügü terör örgütlerince bir firsat olarak görülmekte ve aktif bir şekilde propaganda amaçlı kullanılmaktadır. Bu durum yerel bazlı kitlesel hareketleri küresel bir boyuta taşıyarak tehlikeli bir noktaya ulaştırmaktadır.

Yaşadığımız dönemde insanlar her gün sosyal medyayı aktif şekilde kullanmaya başlamışlardır. Bu durum bireylerin, iletişim alışkanlıklarını da değiştirmiştir. Sosyal medyanın etkisi ve gücü Arap Baharı olarak ya da "Twitter Devrimi" olarak adlandırılan olaylar zincirinde bariz bir şekilde görülmüştür. Sosyal medya, bu bağlamda en etkili şekilde Mısır'da kullanılmıştır. Sosyal medyada yapılan propaganda faaliyetlerinin başarıya ulaşmasında rejimin sosyal medya teknolojisini kontrolünde tutamaması önemli bir noktadır. Sosyal medya bu etkisi ile toplumsal örgütlenme için önemli bir konuma gelmiştir (Telli, 2012: 66,67).

İşte tam bu noktada örgütler aktif şekilde sanal ortamlara yönelerek mesajlarını iletmeye başlamışlardır. Bu tehlike göz önüne alındığında araştırmaya ve analiz yapmaya değer bir konu olarak karşımıza çıkmaktadır. Bu çalışma terör örgütü DEAŞ'ın sosyal ağlarda gerçekleştirdiği propaganda faaliyetlerini ayrıntılı bir şekilde ele almaktadır.

Terör örgütü gerek Türkiye'de gerekse diğer ülkelerde farklı isimlerle ifade edilmektedir. $\mathrm{Bu}$ çalışmada terör örgütünün ismi olarak DEAŞ ifadesinin kullanılmasının nedeni Türkiye Cumhuriyeti İçişleri Bakanlığının örgütü bu isimle nitelendirmesidir.

Çalışmanın ana önceliğini sosyal medya ve sosyal medyanın DEAŞ terör örgütü tarafından nasıl kullanıldığı ve Türkiye özelinde yapılan mücadele oluşturmaktadır. Bu nedenle propaganda kavramına, propagandanın doğuşuna ve terör propagandasına kısaca değinildikten sonra DEAŞ'ın sosyal medya yapılanması 
incelenecek ve sosyal medyada paylaşım sorumluluğu ile hukuki mücadele irdelenecektir. Son olarak elde edilen veriler ışığında yapılabilecekler konusunda önermeler belirlenmeye çalışılacaktır.

\section{Kavramsal Olarak Propaganda ve Propagandanın Doğuşu}

Propaganda kelimesinin kökeni Latince "propagare" sözcügüne dayanır. "Propagare" sözcüğü bitki filizlerinin yeni bir bitki elde ekmek için toprağa dikilmesi anlamına gelir. Bu kapsamda propaganda sözcüğü, belirli bir fikir ve düşünceyi yaymak ve yerleştirmek manası için kullanılan bir kavramdır (Atabek, 2003: 5). Türk Dil Kurumu propagandayı "Bir öğreti, düşünce veya inancı başkalarına tanıtmak, benimsetmek ve yaymak amacıyla söz, yazı vb. yollarla gerçekleştirilen çalışma" şeklinde tanımlamaktadır (www.tdk.gov.tr). Yüksel (2014: 10) ise propagandayı "çok sayıda insanın düşünce ve davranışlarını etkilemek amacını taşıyan önceden planlanmış bir mesajlar bütünü" olarak tanımlamaktadır.

Qualter (2017: 279, 280), uluslararası bağlamda propaganda aracılığıyla girişilen ve girişilecek olan edinimlere anlam kazandırmak maksadıyla alternatif tanımlar ortaya atmıştır. Bu tanımlara göre propaganda:

- $\quad$ Bir bireyin veya grubun, başka bireylerin veya grupların tutumlarını belirleyip biçimlendirmek, kontrol altına almak veya değiştirmek için; haberleşme araçlarından yararlanarak ve bu bireylerin veya grupların belirli bir durum veya konumdaki tepkilerinin kendi amaçlarına uygun tepkiler şeklinde olacağını umarak giriştikleri bilinçli bir faaliyettir.

- Başka grupların tutumları üzerinde kontrol kurmak veya bunları değiştirmek veya biçimlendirmek için yapılan bir girişimdir.

İletişim bilimci Lasswell (1928: 9); "anlamlı semboller ya da öyküler, söylentiler, haberler, resimler ve toplumsal iletişimin diğer biçimleri ile düşüncelerin denetimi" tanımını yaparak propaganda kavramına yeni bir anlayış getirmiştir. Ker’in (1998: 270) belirttiğine göre Doop, propagandanın temelini telkin kudretine dayandırmaktayken, Lasswell, kasıtlı olarak fikir ve düşünceleri aşılama etkinliği olarak açıklamaktadır. Ker ise kavramı, bir düşünceyi yayarak ona yandaş toplama tekniği olarak ifade etmektedir. 
Hukuk açısından propagandanın tanımına bakarsak Türk Ceza Hukuku'na göre Yargıtay 8. Ceza Dairesi propagandayı, "bir düşünceyi yandaş kazanmak için birden fazla kişinin bilgisine duyurmak, iletmek, ulaştırmak amacıyla yayma hareketi" (Yargitay, 2017) olarak tanımlamaktadır. Bu tanımlardan hareketle propagandayı, belirli bir fikri herhangi bir etik ilkeye bağlı kalmaksızın hedef kitleye ulaştırarak istenilen tutum değişikliğinin oluşması için gerçekleştirilen iletişim faaliyeti olarak tanımlayabiliriz.

Propaganda, dünya tarihinin her döneminde kitlelerin fikir, davranış ya da tutumlarını etkileme amacına yönelik önemli bir araç olarak görülmüştür. Birçok lider propaganda ile kendi inandıkları düşünceleri kitlelere benimsetme gayretinde olmuşlardır (Geçikli, 1999: 265). Hitler'in, "Ustaca hazırlanmış bir propaganda ile insanları cennetin cehennem olduğuna ve cennette en sefil hayatın yaşandığına inandırmak mümkündür" ve "Propaganda sayesinde iktidara geldik, propaganda sayesinde dünyayı fethedeceğiz", Mussolini'nin "Bir efsanenin mutlaka doğru olması gerekmez" (Kayabalı ve Arslanoğlu, 1983: 14) ve Lenin'in "Önemli olan bütün toplum katmanlarında kargaşa çıkarmak, propaganda yapmaktır" (Domenach, 2003: 15), ifadeleri bu görüşü desteklemektedir.

Pek çok tanımı bulunan propagandanın doğuşu hakkında birçok görüş mevcuttur. Atabek (2003: 5), propagandanın başlangıcının yazılı tarihten daha eski olduğunu ve konuşmanın gelişmesiyle birlikte başladığını varsaymaktadır. Eski Yunan, Roma, Ortaçağ, Napolyon ve Dünya Savaşları dönemlerinde birçok propaganda faaliyetinin varlığından söz edilmektedir. Konu ile ilgili olarak yapılan çalışmalar incelendiğinde propaganda kavramının 1622 yılında Papalık tarafından Katolik kilisesinde oluşturulan ve inanç yapma örgütü olarak faaliyet gösteren İnancın Yayılması İçin Roma Katolik Kutsal Meclisi'nin isminden (Sacra Congregatio Christiano Nomini Propagando) geldiği anlaşılmaktadır (Başdoğan, 1960:234). Propagandanın kavram olarak ortaya çıkışı belli olsa da bir isimle ifade edilmeksizin insanlık tarihi boyunca sürekli olarak kullanıldığı bilinmektedir.

Bu kullanımlara kısaca bakacak olursak; Moğollar savaş alanına gelmeden önce kendilerinin çok güçlü oldukları ve ortalığı yakıp yıkacakları ile ilgili propaganda faaliyeti yürüterek psikolojik üstünlük sağlamayı planlamışlardır (Tarhan, 2003: 5). 
Şah İsmail'in dedesi olan Şeyh Cüneyd de Oğuz boyları arasında "Oğul mu önce gelir, yoksa sahabeler mi?” söylentisi çıkartarak propaganda faaliyeti yürütmüştür (Sarı, 2016: 57). Osmanlı İmparatorluğu'nda ise hükümet propaganda faaliyetlerini tellallar aracılığıyla yürütürken, sonraki dönemde ilk resmi gazete olan Takvim-i Vekayi propaganda aracı olarak kullanılmıştır (Güngörmez, 2002;2,3). Milli Mücadele döneminde de İrade-i Milliye ve Hakimiyet-i Milliye gazetelerinin yanı sıra Halide Edip Adıvar ve Yunus Nadi tarafindan 1920 tarihinde kurulan Anadolu Ajans1 propaganda faaliyetlerinde bulunmuş ve yeni kurulan devletin prensiplerini benimsetmeyi amaçlamıştır.

\section{Propaganda Türleri ve Teknikleri}

Propaganda türlerini sekiz başlık altında sınıflandırmak mümkündür. $\mathrm{Bu}$ sınıflandırmalar şu şekildedir (Özdağ, 2015: 34-42);

- $\quad$ Seviyesine göre propaganda: Stratejik, Taktik

- $\quad$ Konusuna göre propaganda: Ticari, Dinsel, Siyasal, Askeri

- $\quad$ Yöntemine göre propaganda: İkna edici, Korkutucu-Yıldırıcı, Kışkırtıcı

- $\quad$ Amacina göre propaganda: Propaganda, Karş1 Propaganda

- $\quad$ Hedef topluma göre propaganda: İstikrarcı, Yıkıc1-Bölücü, İkna Edici

- $\quad$ Kapsamına göre propaganda: Genel, Sınırlı, Ferdi

- $\quad$ Düzlemine göre propaganda: Dikey, Yatay

- $\quad$ Kaynağına göre propaganda: Beyaz, Kara, Gri

Gelişen teknolojiler ile birlikte propaganda yapıcıların kullandıkları tekniklerde değişmekte ve gelişmektedir. Dolayısıyla propagandada kullanılan teknikler değişip geliştikçe beklentiler de değişmektedir. Bu bağlamda araştırmacılar propagandayı klasik ve modern olarak ikiye ayırmaktadır. Klasik propaganda bireyin tutumunun değiştirilmesini amaçlarken, modern propaganda ise bunun yanında bireyin aktif olarak süreçlere katılmasını sağlamak ve alternatif bir seçenek bırakmadan bireyde tepki ve inanç oluşturulmasını da amaçlamaktadır (Bektaş, 1996: 159). 
Propagandayı etkin kılmak amacıyla birçok teknik kullanılmaktadır. Bu teknikleri Jowett ve O’Donnell (2012: 299), iletişim kaynağının tekelleşmesi, izleyicide eğilimler yaratmak, kaynağın inanılırlığı, ödül ve ceza, kanaat önderleri, görsel sembollerin gücü, yüz yüze iletişim, grup normları, dilin etkili kullanımı, müzik (marş, şiir vb.), duyuların uyarılması (dini, milli, yerel vb.) ve karşı propaganda şeklinde sıralarken, Aksoy (www.temelaksoy.com) şu şekilde sıralamaktadır:

- $\quad$ Propagandacı karalamak istediği kişi ve/veya gruba olumsuz çağrışımlar yapan "yılan" ya da "örümcek" gibi isimler takar.

- $\quad$ Propagandacı objektif kanıtlar kullanmak yerine kimsenin itiraz etmeyeceği genellemeler yapar. "Vatan", "millet", "ahlak" gibi kavramlar kullanır.

- $\quad$ Propagandacı simgeler kullanır. "Bayrak" ya da "dini kitaplar" vb.

- Propagandacı kendi fikirlerini yayarken toplumun beğenisini ve saygısını kazanmış, söylediklerine inanılan ünlüleri kullanır.

- Propagandacı sıradan insanların başına gelmiş, az rastlanılan olayları örnek olay olarak anlatır.

- $\quad$ Propagandacı insanların bilgisinin olmadığı konularda bazı verileri abartır ya da çarpitır.

- $\quad$ Propagandacı hiçbir kanıt göstermeden herkesin kendi fikrini benimsediğini iddia eder.

- $\quad$ Propagandacı çok sık söylendiğinde insanların belleklerine kazınan güçlü ve abartılı ifadeler kullanır.

- $\quad$ Propagandacı kendi fikrini anlatırken "ya hep ya hiç" şeklinde kutuplaşma yaratacak şekilde anlatır ve seçim yapmanızı ister.

- Propagandacı dost ve düşman yaratır. Seçiminizi dosttan yana yapmıyorsanız düşmandan yana olduğunuz sonucunu çıkartır.

Buradan hareketle bir propaganda programının önemli noktaları, inanç ve tutumların kontrolünde hedefleri sınırlamak, heyecan ve motivasyon faktörünü denetlemek, inanç ve tutumların tasarlanmasında yapılan hataları önlemek, inanç ve 
tutumlarda etkili olan ideolojileri değiştirmektir. Propaganda faaliyetinde başarılı olmak için, kitlelerin dikkatinin çekilmesi ve güveninin kazanılması, umut ve beklentileri ile ilgili alternatiflerin sunulması ve eyleme geçirmeye hazır hale getirilmesi önemli hususlardır (Kayabalı ve Arslanoğlu, 1982: 11-28).

\section{Terörizm Boyutu ile Propaganda}

Terör ve propaganda kavramlarını bir araya getiren temel unsur bizzat terörün kendisinin bir propaganda faaliyeti olmasıdır. Gerek bireysel gerekse örgütlü olsun bir terör eylemi toplum tarafından duyulmuşsa propaganda faaliyeti başlamış demektir. $\mathrm{Bu}$ nedenle terör propagandasını anlayabilmek için öncelikle terör kavramını açıklamak gerekir. Milletler Cemiyeti 1937 yılında "Terörizmi Önleme ve Cezalandırma Sözleşmesi" hazırlamış, sözleşme 24 devlet tarafından imzalanmasına rağmen yürürlüğe girmemiştir. Bu sözleşmenin birinci maddesinde terör "genel halk, gruba ait bir kişi ya da belli bir kişi tarafından doğrudan devlete karşı terör durumu yaratmak için plan yapmak veya buna niyetlenme gibi suç oluşturan eylemler" olarak sınıflandırılmıştır (Tekel, 2017: 1356). Türkiye'de ise terörün tanımı 3713 sayılı Terörle Mücadele Kanunu'nun 1. maddesine göre (Terörle Mücadele Kanunu, 2017)

Terör; cebir ve şiddet kullanarak; baskl, korkutma, yıldırma, sindirme veya tehdit yöntemlerinden biriyle, Anayasada belirtilen Cumhuriyetin niteliklerini, siyasî, hukukî, sosyal, laik, ekonomik düzeni değiştirmek, Devletin ülkesi ve milletiyle bölünmez bütünlüğ̈̈nü bozmak, Türk Devletinin ve Cumhuriyetin varlı̆̆ını tehlikeye düşürmek, Devlet otoritesini zaafa uğratmak veya ylkmak veya ele geçirmek, temel hak ve hürriyetleri yok etmek, Devletin iç ve dlş güvenliğini, kamu düzenini veya genel să̆ll̆̆g bozmak amacıyla bir örgüte mensup kişi veya kişiler tarafindan girişilecek her türlü suç teşkil eden eylemlerdir.

Terör propagandası ise terör ile başlayan ve devam eden bir süreci ifade etmektedir. Bu bağlamda Karaarslan (2014: 319), terör propagandasını "terör eylemlerinin tümünü muhatap kitleye hoş gösterecek şekilde muhtelif araçlar kullanılarak yapılan faaliyetin bütünü olarak" tanımlamaktadır. Demokratik yöntemle amaçlarına ulaşamayan gruplar kendi etkinliklerini ve güçlerini ispatlamak için terörü bir reklam ve propaganda yöntemi olarak kullanmaktadırlar (Fendoglu, 2017: 2). Özellikle sosyal medyanın olmadığı dönemlerde terör örgütleri yaptıkları eylemlerle geleneksel kitle iletişim araçlarının dikkatini çekmeye ve yaptıkları eylemlerin bu 
araçlarda yer almasıyla kendi propagandalarını yapmaya çalışmışlardır. Terör eylemlerinin yanı sıra kendilerine yakın olan kişilere kurdurdukları sivil toplum kuruluşları aracılığı ile de propagandalarına yasal sınırları içerisinde devam etmiş ve etmektedirler. Bunun en önemli nedeni bazı ülkelerin bu terör örgütlerini ve onlar tarafından kurulan sivil toplum görünümlü kuruluşları yasal kabul etmeleri ve desteklemeleridir. $\mathrm{Bu}$ tür yapılar aynı zamanda yasal boşluklardan da yararlanmaktadır.

$\mathrm{Bu}$ şekilde çalışan terör örgütlerine verilebilecek en uygun örnek Ermeni terör örgütü ASALA'dır. Bu terör örgütünün militanları pek çok ülkede Türk diplomatlarını suikast düzenleyerek öldürürken Ermeni sivil toplum kuruluşları da boş durmamış, yapılan terör faaliyetlerini haklı göstermeye çalışmışlardır. Örneğin, dünyanın farklı noktalarına birçok anıt dikmişlerdir. Bu sayede Ermenilerin sözde masumiyetini ve sözde mağduriyetini anıtlaştırmayı amaçlayan ve çerçeveleme etkisi yaratan bir politika oluşturmuşlardır. Bu yöntem bir propaganda stratejisidir. Nitekim propaganda görevlileri ve militanlar, rakiplerininkini sindirecek şekilde afişler asmaya, bildiri dağıtmaya, slogan atmaya, sloganlarıyla duvarları donatmaya çalışırlar (Bilgin, 26.04.2017). Önceleri kaçırma, öldürme gibi korku ve yıldırma yöntemleri ile propaganda faaliyetlerinde bulunan terör örgütleri günümüzde yine bu yöntemleri kullanmakta ve geleneksel medyada yer almaktadır. Ancak geleneksel medyanın kontrol edilebilir yapısından dolayı propaganda mesajlarını kontrol edilemeyen sosyal medya üzerinden vererek etkilerini arttırmayı hedeflemektedirler.

\section{Propaganda Aracı Olarak Sosyal Medya}

Mayfield (2017: 5) sosyal medyanın, aşağıdaki özelliklerin pek çoğunu veya tamamını barındıran yeni bir çevrimiçi medya olduğunu belirtmektedir:

- Katılım: Sosyal medya ilgilenen herkesin katkı yapmasını ve geri bildirimi teşvik eder. Medya ve kullanıcılar arasındaki kesin çizgiyi belirginlikten uzaklaştırır.

- $\quad$ Açıklık: Birçok sosyal medya aracı geribildirime ve katılıma açıktır. Kullanıcılarını oy verme, yorum yapma ve bilgi paylaşımı gibi konularda teşvik ederler. Bunlar erişime yönelik neredeyse hiçbir kısıtlama koymazlar. 
- $\quad$ Sohbet: Geleneksel medya yayın yapma üzerine kuruluyken (bir kitleye iletilen veya dağıtılan içerik), sosyal medya çift yönlü bir sohbet aracı olarak görülür.

- $\quad$ Toplum: Sosyal medya toplulukların hızlı bir şekilde oluşmalarına ve etkili iletişim kurmalarına izin verir. Topluluklar da böylece sevdikleri fotoğrafları, politik konuları ve favori TV şovları gibi ilgili oldukları şeyleri paylaşırlar.

- Bağlantılılık: Çoğu sosyal medya birbirlerine bağlantılılıklarından dolayı gelişmekte; diğer sitelere, kaynaklara ve insanlara bağlantı kurmaya olanak tanımaktadır.

Yukarıda belirtilen içeriklerin yanında sosyal medyanın dört temel özelliği daha mevcuttur. Bu özelliklerin ilki kullanıcıların çeşitli medya türlerinde içerik oluşturabilmesi ve bu içeriklere katkı sağlayabilmeleridir. İkincisi, kullanıcıların içerikleri etiketleyebilmeleridir. Üçüncüsü, kullanıcıların kullandıkları içerikleri aktif ya da pasif kullanım ile değerlendirebilmeleridir. Son olarak ise kullanıcılar karşı1lıklı olarak ortak ilgi alanları tanımlayarak sosyal ağlarını kurabilmektedirler (Lerman, 2017: 16). Bu durum sosyal ağların, hızlı ve kolay tepki vermeyi sağlayan, organize olmanın kolay olduğu ve geleneksel medyadan farklı olarak bireyi merkezine alan bir yapıya sahip olmasından kaynaklanmaktadır.

Herman ve Chomsky (2012: 72) propaganda modelini açıklarken, medyada aşamalardan oluşan süzgeçlerden bahsetmektedir. Bu modele göre haber, medyada yer almadan önce bu süzgeçlerden geçer ve medyada yer alır. Gelişen iletişim teknolojileri, yeni medyanın keşfi ve sosyal medya ağlarının yaygınlaşması bu süzgeçleri ortadan kaldırarak bireye yeni bir alan açmıştır. Bu noktada sosyal medya denetimsiz ve terör propagandasına açık bir alan olmuştur. Yaşadığımız yüzyılın iletişim araçlarının başında gelen sosyal medya ortamları bütünleşme ve sosyolojik propaganda uygulamaları için kullanılmaktadır (Çetin, 2014: 262). Sosyal medya birçok içeriği tek bir platformda iletme özelliğine sahiptir ve kitlelere kolaylıkla ulaşarak onların duygu, düşünce ve davranışlarını etkiyebilmektedir. Bu durumu Barrett ve Braham (Arslan, 2005: 10-11), "sistematik olarak ve periyodik bir şekilde yinelenerek sergilenen görüntü ve imgeler, özellikle de çocukların ve gençlerin cinsiyet, meslek ve siyasetle ilgili ĕgilim, tutum, duygu, düşünce, değer, beklenti ve 
davranışlarında yoğun bir şekillendirici ve belirleyici etki yapmaktadır" şeklinde açıklamaktadır.

Doğası gereği, internet ve sosyal medya birçok açıdan terörist örgütlerin faaliyet alanı olarak ideal bir mekân oluşturmaktadır. Terör örgütlerince bu mecraların kullanılmasındaki en önemli nedenler ise (Weimann, 2017: 3);

- Kolay erişim,

- $\quad$ Düzenleme, sansür veya hükümet denetiminin diğer tekniklere oranla çok az oluşu veya hiç olmayışı,

- Dünyanın geneline yayılmış büyük kitleler,

- $\quad$ İletişimin gizli kalması,

- Hızlı bilgi akışı,

- Web varlığının ucuz gelişimi ve bakımı,

- $\quad$ Multimedya ortamı (metin, grafik, ses ve video birleştirme yeteneği ve kullanıcıların filmleri, şarkıları, kitapları, posterleri vb. indirmelerine izin verilmesi),

- İnterneti hikâyeler için bir kaynak olarak artan oranda kullanan geleneksel kitle iletişim araçlarında kapsamı şekillendirme becerisi olarak siralanabilir.

Teröristler, potansiyel militanlara ve destekçilere ulaşmak için çeşitli araçlar ve taktikler kullanan uyarlayıcı düşmanlardır. Ne yazık ki, gençlerin dünya çapında faaliyet gösteren terör örgütleri saflarına çekildiğine dair artan kanıtlar bulunmaktadır. Terörist gruplar, çeşitli bağlamlarda, mali yardımdan ailesel bağlara kadar, grup üyeliğini cazip hale getirmek için tasarlanmış çeşitli teşvikler sunarak genç kişilerin hassasiyetlerine sistematik bir şekilde hitap etmektedirler. İnternet, erişilebilir, ucuz ve anonimdir. Teröristlere mesaj dağıtmak için çeşitli araçlar sunar ve işe alımlar için bağlantılar sağlar. Pek çok terörist grup, interneti, gençleri kendi saflarına çekmek ve üye yapmak için bir araç olarak kullanmaktadır. Bazı gruplar, çevrimiçi platformları, ilgi alanlarına hitap eden içerikleri yaymak ve bu içerikleri internet platformlarını 
kullanarak gençler arasında yeni içerik üretmek amacıyla kullanmaktadır (Bott ve vd., 2017: 1).

Weimann (2017: 5-10), çağımız teröristlerinin interneti kullandıkları sekiz farklı alan belirlemiştir. Bunlardan bazıları, herkesin internet-bilgi toplama yöntemlerini kullanmasına paraleldir. Bazıları, geleneksel siyasal örgütler tarafından medyanın kullanımlarını andırmaktadır; örneğin, para toplama ve propagandanın yaygınlaştırılması. Bununla birlikte daha sıra dışı ve ayırıcı özellik taşıyabilir; örneğin, kodlanmış mesajlardaki veya şifreli dosyalardaki talimatları, el kitaplarını ve açık talimatları gizlemek gibi. Teröristlerin interneti kullanım alanları şu başlıklar altında siralanabilir:

- Tanitım ve Propaganda

- $\quad$ Psikolojik Savaş

- $\quad$ Veri Madenciliği

- Băğ $\quad$ Bş

- $\quad$ İstihdam ve Seferberlik

- $\quad$ Networking

- $\quad$ Bilgi Paylaşımı

- $\quad$ Planlama ve Koordinasyon

Çok farklı siyasi hedefleri olan gruplar, terörist taktiklerini kullanmaya hazır olduklarında, bir araya gelerek grup propagandasını yapmak, destekçileriyle iletişim kurmak, kamuoyunu bilinçlendirmek, sempati oluşturmak ve hatta operasyonlarını yürütmek için sosyal ağları kullanmaktadır. Amerika Birleşik Devletleri Barış Enstitüsü Özel Raporuna göre aktif olarak sosyal ağları kullanan terörist gruplardan bazıları şu şekilde listelenmiştir (Weimann, 2017: 3-4):

- $\quad$ Ortadoğu: Kürdistan İşçi Partisi (PKK) ve Devrimci Halk Kurtuluş Partisi-Cephesi (DHKP / C).

- $\quad$ Avrupa: Bask ETA hareketi ve İrlanda Cumhuriyet Ordusu (IRA). 
- $\quad$ Latin Amerika: Peru'nun Tupac-Amaru (MRTA), Kolombiya Ulusal Kurtuluş Ordusu (ELN-Kolombiya) ve Kolombiya Silahlı Devrimci Kuvvetleri (FARC).

- $\quad$ Asya: Japon Kızıl Ordu (JRA), Asya El Kaide.

Yayınlanan listeye günümüzde yapılabilecek en önemli ekleme DEAŞ' dır.

Terör örgütlerinin neden sosyal medyaya bu kadar ilgi duyduklarını anlayabilmek için sosyal medya kullanıcılarının sayısına da bakmak gerekir. We Are Social tarafindan hazırlanan "Dijital In 2017" raporuna göre (www.wearesocial.com), dünyada 3.773 milyon insan internete bağlanırken 2.789 milyon insan ise aktif olarak sosyal medya kullanmaktadır. Dünya'da en çok kullanılan sosyal medya platformlarına baktığımızda ilk sırada 1.871 milyon kişi ile Facebook bulunmaktadır. Messenger, WhatsApp ve YouTube 1'er milyar kişi ile sırasıyla ikinci, üçüncü ve dördüncü sıradadır. Instagram 500 milyon kişi ile dokuzuncu ve Twitter 317 milyon kişi ile onuncu sırada bulunmaktadır (bölgesel sosyal ağlara yer verilmemiştir). 2016 yılı itibariyle Türkiye Cumhuriyeti'nde adrese dayalı nüfus kayıtları sonucuna göre 79 milyon 814 bin 871 kişi yaşamaktadır. Türkiye'de, 1998 tarihinde internet abone sayısı 229.885 kişi iken, 2010 yılında 14.443.644 kişi ve 2017 yılında ise 64.335.111 kişi olmuştur (www.tuik.gov.tr). Yine We Are Social "Dijital In 2017" raporuna göre (www.wearesocial.com), Türkiye'de 48 milyon aktif sosyal medya kullanıcısı bulunmaktadır. Türkiye'de en çok kullanılan sosyal medya platformlarına baktığımızda ilk sırada \%57 ile YouTube'u görüyoruz. YouTube'u \%56 ile Facebook, \%45 ile Instagram, \% 44 ile Twitter, \%40 ile WhatsApp ve \%36 ile Messenger takip etmektedir. Sosyal medyanın kullanıcı açısından ulaştığı bu rakamlar dikkate alındığında terör örgütlerinin sosyal medyaya olan ilgisi ortaya çıkmaktadır.

\section{DEAŞ ve Sosyal Medya Propagandası}

Terör örgütleri gerçekleştirdiği eylemleri duyurmak, finansman ve destekçi kazanmakla beraber, meşru bir zemin oluşturabilmek için kitle iletişim araçlarına ihtiyaç duymaktadır. Terör örgütleri bu amaçlarla günümüzde propaganda aracı olarak internet kanallarını etkin bir şekilde kullanmaya başlamışlardır (Purdy, 2017: 7). Terör örgütlerinin çevrimiçi platformları kullanmaları yeni bir gelişme değildir. 11 Eylül 
sonrası artan antiterör eylemleri çok sayıda terörist grubu internet mecrasına yönelterek mesaj ve etkinliklerini teşvik edici binlerce web sitesi kurmalarına sebep olmuştur. Terör bölgelerinde istihbarat ve kolluk kuvvetlerinin bu siteleri takip ederek müdahale etmesi, terörist grupları alternatif çevrimiçi alanlara yöneltmiş ve böylece sosyal ağlara geçiş süreci tamamlanmıştır (Weimann, 2014: 2). Sosyal ağlarda hesap açmanın çok kolay olması ve sahte hesaplar bu süreci hızlandırmıştır.

DEAŞ terör örgütünün sosyal medya kullanımı incelendiğinde hem resmi hem de gayri resmi sayfalar kullandıkları görülmektedir. Bu sayfalarda DEAŞ "cihat" kelimesini ön plana çıkarmış ve "Cihad Sosyal Medyası" internet ortamında yayılarak DEAŞ'ın cephaneliğindeki en önemli silahlardan biri haline gelmiştir. Facebook, Twitter, YouTube, sohbet odaları, bloglar, mesajlaşma sistemleri ve çok sayıda sosyal medya platformu, DEAŞ'ın savaşçıları ve destekçileri tarafından gerçekleştirilen şiddet eylemlerini yansıtıp sergilemektedir (Purdy, 2017: 7). Bu durum DEAŞ'a propaganda üstünlüğü sağlamakta ve istediği konuları ön plana çıkararak gündem oluşturmasına katkı sunmaktadır.

DEAŞ'ın sosyal medya propagandası zafer halifeliği, pastoral halifelik ve seferberlik olarak üç temel başlık altında ele alınmaktadır. Zafer halifeliği olarak adlandırılan stratejinin ana teması, grubun olağanüstü derecede güçlü olması, sürekli yeni topraklar kazanması ve momentuma sahip olmasıdır. DEAŞ, meşruluğunu, halifelik kurma, savunma ve genişletme olgularına dayandırmaktadır. Pastoral halifelik stratejisi ise DEAŞ'ın acımasızlığı ile askeri istismarları temelinde grubun, kendisini yetenekli bir vali olarak tanıtma çabası doğrultusunda halifeliğin İslami bir ütopya olduğu algısını yaratma çabasıdır. DEAŞ, şeriatı (İslam hukuku) uygulayabildiğini ve "vatandaşlarına" temel hizmetleri verebildiğini göstermeye çalışmaktadır. DEAŞ, hâkim bir varlık olarak kimlik bilgilerini kanıtlayamadığından dolayı halifelik projesinin bütünlügü sorgulanmaktadır. Aksine, halifeliğin işleyen ve şahsiyet halindeki bir devlet olduğunu gösterirse, grup hem "cihatçı" rakibi El-Kaide hem de bölgedeki sünni devletlere kıyasla meşruiyetini artırabilir. DEAŞ, taraftarlarını harekete geçirme konusunda benzeri görülmemiş bir başarıya imza atmaktadır. Bunun nedeni büyük ölçüde sosyal medya hâkimiyetidir. Grubun propaganda faaliyetleri, yabancı savaşçıları, halifeliğe çektiği göçmenleri ve Batı'daki bireyleri DEAŞ adına 
saldırı yapmaları için teşvik edici bir niteliğe sahiptir. Bugüne kadar yaklaşık 30.000 yabancı savaşçı ve göçmen, 2011'den beri "cihat" gruplarına katılmak için Suriye ve Irak'a gitmişlerdir. Bu herhangi bir "cihat" hareketinin çektiği en büyük yabancı savaşçı sayısıdır (Ross, 2017: 20-23). DEAŞ, sosyal medya üzerinden yaptığı propagandalar ile savaşçılarını, Müslümanların rol modelleri olarak sunmak ve onları ölümsüzleştirmekle beraber, kendi toplumlarında marjinal görüldüklerine yönelik bir his yaratarak kendi kurduğu yapıyı çekici kılmayı arzulamaktadır (Weimann, 2014:2).

Duhaime, (2015:1) DEAŞ'ın dijital terör stratejisinin temelde dört başlıktan oluştuğunu tespit etmiştir.

- $\quad$ Batıdan kaçan kişilerin istihdamı ve yalnız kurtları harekete geçirmek,

- Dünyanın geri kalanı ile agresif şekilde çevrimiçi iletişim kurmak ve genç insanları terörizmle büyüleyerek sosyal bağlamın dışına çıkarmak,

- Acımasız eylemlerle medyanın dikkatini çekmek ve DEAŞ'ın finansörlerine satın alma kanıtı sunmak,

- $\quad$ Sosyal medya platformları aracılığgyla finansman talep etmek.

DEAŞ'ın propaganda içeriği üretmek ve dağıtmakla görevli birkaç medya bürosu vardır. Al-Furqan ve al-I'tisaam ajansları Arapça filmleri üretmektedir. AlHayat Medya Merkezi, batılı izleyiciler için film ve yayınlardan sorumludur. Al-Ajnad ise dini içerikli yayınlar yapmaktadır. "İslam Devleti" ayrıca "İslami Hilafet"in topraklarında propaganda yapan al-Bayan adlı bir radyo istasyonuna ve Twitter'da ilgili haberleri veren bir haber ajansına sahiptir. Bu önemli ajanslara ek olarak, "İslam Devleti" sınırları içindeki her ilde, videoların filme alınması ve dağıtılması için yerel medya büroları vardır. Bu bürolar bölgedeki güncel olaylarla ilgili raporlar hazırlamakla sorumludurlar (Hoffman, 2016: 100). Bu medya bürolarının yanı sıra sosyal ağlar DEAŞ'ın en önemli propaganda araçlarıdır. Bu sayede istediği mesajları büyük kitlelere ulaştırabilmektedir. Twitter, Facebook ve YouTube terör örgütünün en fazla kullandığı sosyal ağlardır.

Twitter son dönemde teröristlerin en sevdiği internet hizmeti olarak ortaya çıkmaktadır. Propaganda mesajını yaymak ve dahili iletişimi sağlamak için 
kendilerince tasarlanmış web sitelerinden ya da Facebook'tan daha popüler olarak kullanılmaktadır. Terör örgütleri Twitter sayesinde gerçek zamanlı gündem yaratabilmekteler. Bu durumda ana akım medya, tweetleri meşru bir haber kaynağı olarak tanımaktadır. Böylece teröristler propaganda mesajlarını tekrarlayarak ana akım medyada görünme imkânı yakalamışlardır (Weimann, 2014:8). Nitekim Brookings'in Mart 2015 tarihinde yapmış olduğu kapsamlı bir çalışmaya göre, "İslam Devleti" taraftarları en az 46.000 aktif Twitter hesabı yönetmektedir. Amerikalı üst düzey yetkililer, organizasyonun günde 90.000 tweet ürettiğini tahmin etmektedir (Hoffman, 2016: 101). Bu kadar çok sayıdaki Twitter hesabının kontrol altına alınması ise kapsamlı bir çalışma ile mümkündür.

Saltman ve Winter (2014: 41) DEAŞ'ın Twitter hesaplarını dört kategoride değerlendirmektedir:

- $\quad$ Resmi haber hesapları: Belirli bir kişiyle bağlantısı olmadan DEAŞ haber ve propagandası yapılan hesaplardır.

- Gayri resmi haber hesapları: DEAŞ destekçilerinin geniş bir kitleyi haberdar etmek için kullandıkları hesaplardır.

- Bölgesel haber hesapları: Belirli bir bölgeden resmi haber akışı sağlamaktadır.

- $\quad$ Kişisel hesaplar: Savaşçı ve destekçilerinin Suriye ve Irak'taki olaylar hakkında paylaşım yaptıkları hesaplardır.

Türkçe konuşan örgüt üyelerinin de Twitter üzerinden yoğun bir propaganda stratejisi mevcuttur. Türkçe konuşan örgüt üyelerinin ve sempatizanlarının Twitter'daki önceliklerinin din olmadığı, daha çok dünyevi hareket ettikleri gözlemlenmektedir (Orsam, 2016: 3). DEAŞ kurumsal olarak tanımlanabilecek Twitter hesaplarında ise infaz görüntüleri ve DEAŞ sınırları içerisinde yaşayan insanların yaşamlarından kesitler paylaşmaktadır.

Facebook kullanımı açısından bakıldığında ise, DEAŞ için, resmi ve gayri resmi olmak üzere iki tür Facebook sayfası tanımlanabilir. Resmi sayfalar genellikle diğer internet sitelerinde yer alan bilgileri ve örgüt tarafından üretilen materyalleri yaymak amaciyla faaliyet göstermektedir. Resmi olmayan sayfalar ise örgütün 
sempatizanları tarafından, propaganda ve/veya öğretim materyallerini yaygınlaştırma amacı ile yönetilmektedir (Weimann, 2014: 6). DEAŞ'ın resmi olarak tanımlanabilecek Facebook hesaplarında ise Müslümanların zulüm gördüğüne yönelik paylaşımlarla ideolojik altyapı oluşturulmuş ve eylemlerin meşruiyetini sağlamak amaçlanmıştır.

Amerika Birleşik Devletleri İç Güvenlik Bakanlığı tarafından hazırlanan bir rapora göre Facebook'un çeşitli terör amaçlı kullanımları listelenmektedir. Bu listeye göre Facebook (Weimann, 2014:6);

- $\quad$ Bomba tarifleri gibi operasyonel ve taktiksel bilgileri paylaşmanın bir yolu olarak (silah bakım ve kullanımı, taktik çekim vb.),

- Bağlantılar ile aşırılık yanlısı sitelere ve diğer çevrimiçi radikal sayfalara geçiş noktası olarak grup sayfaları ve tartışma forumları,

- $\quad$ Propaganda ve aşırı radikal ideolojik mesajların iletilmesi için bir medya merkezi olarak,

- $\quad$ Hedef belirlemek amaciyla uzaktan keşif için zengin bir bilgi kaynağı olarak kullanılmaktadır.

Video paylaşım hizmeti veren YouTube'da iletişim kurmak, propaganda yapmak, yeni bireyler toplamak ve alt kültürü desteklemek için "cihatçı gruplar" ve taraftarları açısından önemli bir platform haline gelmiştir. YouTube'un etkili küresel kitlesi, "cihat sahiplerinin" terörizm için hem potansiyel askerlere hem de hedeflere aynı anda ulaşabilmelerini sağlamıştır. Paylaşılan videolar kadar YouTube'un cihatçılar arasındaki sosyal ağın genişlemesinde kullanıldığı tespit edilmiştir. Terörist gruplar, kolayca erişilen bu platformun propaganda ve radikalizasyon videolarını yayma potansiyelini fark ederek etkin bir kullanım gerçekleştirmektedirler (Weimann, 2014:10). YouTube ayrıca hem resmi DEAŞ çıktısı hem de kullanıcılar tarafindan oluşturulan videoları barındırmak için kullanılmaktadır. Birden fazla sahte hesap kurarak, videoları paylaştıklarında hızla yayabilmektedirler. Kullanıcılar, özellikle Twitter ve Facebook'taki materyalleri yaymak için kendi sosyal medya hesaplarından YouTube bağlantıları paylaşmaktadırlar (Home Office, 27.05.2017). 
2014 yılında "Irak ve Şam İslam Devleti'nin Yeni Medya Kullanımı" isimli çalışmada DEAŞ tarafından yayınlanan videoların analizi yapılarak bu videoların yayın amaçları; eleman temini, cihat çağrısı ve tehdit gibi temalar şeklinde ortaya konulmuştur (Keskinkaya, 2015: 87). Bu videoların analizleri Tablo 1'de yer almaktadir.

Tablo 1. DEAŞ’ın Video Analizleri

\begin{tabular}{|c|c|c|c|c|}
\hline $\begin{array}{l}\text { ÜRETEN MEDYA } \\
\text { KURULUŞU }\end{array}$ & VIDEO ADI & $\begin{array}{l}\text { VIDEO } \\
\text { SÜRESI }\end{array}$ & VIDEONUN AMACI & $\begin{array}{l}\text { YAYINLANMA } \\
\text { TARIHI }\end{array}$ \\
\hline $\begin{array}{l}\text { Al-Hayat Media } \\
\text { Center }\end{array}$ & $\begin{array}{l}\text { Hakikatin Askerleri } \\
\text { illeri Gidin }\end{array}$ & i 32 & Eleman Temini & 02.06 .2014 \\
\hline $\begin{array}{l}\text { Al-Hayat Media } \\
\text { Center }\end{array}$ & Cihatsız Hayat Yok & $13^{\prime} 22^{\prime \prime}$ & $\begin{array}{l}\text { Cihat Çağrısı ve Şehitliğe } \\
\text { Övgü }\end{array}$ & 19.06 .2014 \\
\hline $\begin{array}{l}\text { Al-Hayat Media } \\
\text { Center }\end{array}$ & $\begin{array}{l}\text { Sykes Picot'un } \\
\text { Sonu }\end{array}$ & $15^{\prime} 03^{\prime \prime}$ & Tehdit, Cihat Çağrısı & 29.06 .2014 \\
\hline Al-Furqan Media & Amerika'ya Mesaj & 04'43" & Tehdit & 19.08.2014 \\
\hline $\begin{array}{l}\text { Al-Hayat Media } \\
\text { Center }\end{array}$ & Haydi Cihada Gidin & $05 ' 26 "$ & Cihat Çağrısı & 02.10 .2014 \\
\hline Al-Furqan Media & $\begin{array}{l}\text { Amerika ve } \\
\text { Müttefiklerine }\end{array}$ & 01' 31" & Tehdit & 03.10 .2014 \\
\hline Al-Furqan Media & \begin{tabular}{|l|} 
Bana Kulak Verin- \\
Bölüm 3
\end{tabular} & 05'33" & $\begin{array}{l}\text { Meşruiyet Kazanmak ve } \\
\text { Batı Kamuoyunda } \\
\text { Hükümetlerine Yönelik }\end{array}$ & 12.10 .2014 \\
\hline Al-Furqan Media & \begin{tabular}{|l|} 
Bana Kulak Verin- \\
Bölüm 4
\end{tabular} & $07^{\prime} 48^{\prime \prime}$ & Doğru Bilgi Vermek & 16.10 .2014 \\
\hline Al-Furqan Media & \begin{tabular}{|l|} 
Bana Kulak Verin- \\
Bölüm 5
\end{tabular} & 06'30" & $\begin{array}{l}\text { Gelir Elde Etmek ve Batı } \\
\text { Kamuoyunda } \\
\text { Hükümetlerine Yönelik }\end{array}$ & 25.10 .2014 \\
\hline $\begin{array}{l}\text { Al-I'tisaam } \\
\text { Foundationfor Media }\end{array}$ & \begin{tabular}{|l|} 
Aynel İslam'ın \\
iççinden
\end{tabular} & $06 ' 30 "$ & Doğru Bilgi Vermek & 27.10 .2014 \\
\hline $\begin{array}{l}\text { Al-Hayat Media } \\
\text { Center }\end{array}$ & Devletimiz Galiptir & 5'09" & Cihat Çağrısı & 09.12 .2014 \\
\hline $\begin{array}{l}\text { Al-Hayat Media } \\
\text { Center }\end{array}$ & $\begin{array}{l}\text { Kanadalı Ebu } \\
\text { Müslim }\end{array}$ & $11^{\prime} 23^{\prime \prime}$ & Cihat ve Destek Çağrısı & 13.12 .2014 \\
\hline
\end{tabular}


DEAŞ'ın sosyal medya alanındaki yaygın faaliyetinin ana sonucu, dünyadaki artan nüfuzu ve küresel bir marka olarak başarıyla kendini pazarlamasıdır. Bu marka, halifeliğin arkasındaki ideolojiyi, düşmanlarına karşı zalimce savaşı gerektiren "sadık" İslam ütopyası olarak sunarken, sadıklar için sosyal adaleti, düzgün yönetimi, haklı ve otantik bir dini ve ahlaki hayatı garanti altına aldığını ifade etmektedir. Batılı izleyiciler çoğunlukla "İslam Devleti" tarafından üretilen korkunç filmlerde tasvir edilen acımasızlığa aşina olsa da, örgütün sosyal medyada sattığı ütopik fikir, yeni üyeler için oldukça caziptir (Hoffman, 2016: 102). Bu bilgilerin yanı sıra DEAŞ internet üzerinden birçok elektronik yayın yapmaktadır. Bu yayınlara, Islamic State News, Dabıq ve Konstantiniyye dergileri örnek olarak gösterilebilir. DEAŞ'ın Türkçe olarak yayınladı̆̆ı "Konstantiniyye" dergisi vasıtasıyla gerçekleştirdiği propaganda sadece Türkiye ile sınırlı değildir. Batı ülkelerinde Türkçe konuşan pek çok insana da ulaşmaktadır (Orsam, 2016: 2). Bu yolla özellikle Avrupa'da DEAŞ adına eylem yapacak kişilere ulaşmak amaçlanmaktadır.

DEAŞ, dört ana nedenden dolayı dijital terörizmde başarılı olmaktadır. Bunlar; Batı'daki terörle mücadele ve istihbarat örgütlerinin gözetiminin gecikmesi, terörle mücadeleyi yürütenlerin gençlere yönelik anlayış eksikliğinden istifade edinen DEAŞ'ın, sosyal medyada terörün yayılmasına yatırım yapmaya devam ediyor olması, kapsamlı ve tutarlı terörle mücadele stratejisi yaratmak için kamu-özel sektör diyalogunun oluşturulamaması ve dijital teröre yönelik herhangi bir tutarlı önlem alınamamasıdır (Duhaime, 2015: 1).

\section{Sosyal Medyada Paylaşım Sorumluluğu ve Propagandaya Karşı Hukuksal Önlemler ve Uygulamalar}

Sosyal medya, yapılan propagandanın hedef kitleye doğrudan ulaşmasına olanak sağlamıştır. Bu durum devletlerin propaganda kaynaklı bilgi akışı üzerindeki kontrolünün geleneksel medyaya göre daha az olmasına neden olmuştur. Bu nedenle devletler internet kaynaklı bilgi akışı ile ilgili düzenlemeler yapmak durumunda kalmışlardır.

Bu düzenlemelere göre, kişilerin sosyal medya aracılığıyla yaptığı paylaşımlar hukuki sorumluluklarına neden olmaktadır. Sosyal medya bireyler arasında bir 
sosyalleşme aracı olarak kullanılan iletişim sürecidir. Bu durum aynı zamanda hukuki boyutları da bulunan bir süreçtir. Sosyal medya aracılığıyla paylaşılan ve haber niteliği taşıyan birtakım içeriklerin paylaşımı yapan kişi yönünden hukuki ve cezai sorumluluklar oluşturabilmesi, haber verme, eleştiri hakkını kullanma ve ifade özgürlüğü kavramları ile birlikte değerlendirilmelidir. Lakin paylaşımcının kişisel yorumlarını katması halinde düşünce, ifade özgürlüğü ve eleştiri hakkı ile haber verme hakkı kavramlarının sınırını aşması ve manevi unsurunun bulunması halinde hukuki ve cezai sorumluluğu söz konusu olacaktır (Taneri, 2016: 434,455).

Sosyal medya ortamındaki paylaşımlar, internet ortamındaki bir yayındır. Bu yayınlar, 5651 sayılı İnternet Ortamındaki Yayınların Düzenlenmesi ve Bu Yayınlar Yoluyla İşlenen Suçlarla Mücadele Edilmesi Hakkındaki Kanun ile düzenlenmektedir. Adı geçen kanun kapsamında değerlendirildiğinde sosyal medya paylaşımını yapan kişinin "içerik sağlayıcı" sıfatı kazandığı ve bu içerikten dolayı sorumlu olduğu görülmektedir. Bu sorumluluk hukuki, cezai ve idari sorumluluk anlamındadır. Öte yandan Türk Ceza Kanunu m.6'da "Basın ve Yayın Yolu" tanımlanmış ve her türlü yazılı, görsel, işitsel ve elektronik kitle iletişim araçları ile yapılan yayınlar olarak ifade edilmiştir. Bu tanımdan, sosyal medya paylaşımlarının da bir tür basın ve yayın eylemi olduğu açıkça görülmektedir. Bazı suç tiplerinde suçun basın ve yayın yolu ile işlenmesi suça nitelik kazandırmakta ve beraberinde ceza artırımı getirmektedir (Doğu, 2016: 18-120). Yine 5651 sayılı kanunun 9. Maddesi teorik olarak başarılı kurulmuş bir uyar-kaldır mekanizması öngörmektedir. Fakat doğrudan kanunun 8. maddesi yoluyla veya Terörle Mücadele Kanunu kaynaklı ya da Medeni Kanun kaynaklı erişim engelleme kararları istenebilmektedir (Koç, 2013: 108).

TCK m. 220/8'e göre terör örgütünün propagandasını yapmak, filli suç işlemek için örgüt kurmak ve yönetmek suçlarından ayrılarak, müstakil bir suç olarak düzenlenmiştir. Maddenin içeriği ise "Örgütün cebir, şiddet veya tehdit içeren yöntemlerini meşru gösterecek veya övecek ya da bu yöntemlere başvurmayı teşvik edecek şekilde propagandasını yapan kişi, bir yıldan ü̧̈ yıla kadar hapis cezası ile cezalandırllır. Bu suçun basın ve yayın yolu ile işlenmesi halinde, verilecek ceza yarı oranında artırılır." şeklindedir (Yurtlu, 2016:404). Yargitay 9. CD, 27.02.2013, 2013/22 E., 2013/2924 K. nolu kararında ise; sosyal paylaşım sitesinde silahlı terör 
örgütü propagandası yapan kişiye verilen cezada, 3713 sayılı Terörle Mücadele Kanunu'nun 7/2. maddesi uyarınca artırım yapılması gerektiğine hükmetmiştir. Terör örgütünün; cebir, şiddet veya tehdit içeren yöntemlerini meşru gösterecek veya övecek ya da bu yöntemlere başvurmayı teşvik edecek şekilde propagandasını yapan kişi, bir yıldan beş yıla kadar hapis cezası ile cezalandırılır. Bu suçun basın ve yayın yolu ile işlenmesi halinde suç nitelik kazanır ve verilecek ceza yarı oranında artırılır (Doğu, 2016: 96). Burada dikkat edilmesi gereken unsur Türk Ceza Kanunu "örgüt" propagandasından bahsederken, Terörle Mücadele Kanunu ise "terör örgütü" propagandasından bahsetmekte ve daha fazla ceza öngörmektedir. Yani sosyal medyada bir organize suç örgütünün propagandasını yapmak ile terör örgütünün propagandasını yapmak arasında kanun hükümlerine göre fark vardır.

Örneğin, Oktay'ın (28.03.2017) haberine göre, Facebook gibi sosyal ağlar üzerinden terör örgütü $\mathrm{PKK} / \mathrm{KCK}$ ve bu örgütün uzantısı diğer terör örgütlerinin simge ve fotoğrafları ile örgüt elebaşı Abdullah Öcalan'ın açık bir şekilde görsellerinin paylaşılması ve beğenilmesi ile benzer dokümanların bulundurulması nedeniyle savc1 sanığın 3713 sayılı Terörle Mücadele Kanunu 7/2 ve Türk Ceza Kanunu 43/1, 53/1, 58/9, ve 63. maddeleri gereğince "terör örgütü propagandası yapmak" suçundan cezalandırılmasını talep etmiştir.

Söz konusu kanunlar doğrultusunda terör örgütü DEAŞ'a yönelik yürütülen mücadelede dikkat çeken hususlar söz konusudur.

Türkiye Cumhuriyeti İçişleri Bakanlığınca, Türkiye'nin terör örgütü DEAŞ'a yönelik mücadelesine yer verilen "Türkiye'nin DEAŞ ile Mücadelesi" (2017: 16-60) kitabı hazırlanmıştır. DEAŞ'ın 30 Eylül 2013 tarihinde Türkiye tarafından terör örgütü olarak tanındığı belirtilen kitapta örgütün eylem biçimleri ile propaganda yöntemlerine ilişsin bilgiler yer almaktadır. Terör örgütünün kadın esirleri erkek militanlarına ganimet olarak paylaştırdığı, pazarlarda birer mal gibi alıp sattığı ve seks kölesi olarak çalıştırdığı ifade edilen kitapta, DEAŞ'ın Türkiye'de 14 terör saldırısı gerçekleştirdiği (10 canlı bomba, bir bombalı ve 3 silahlı saldırı), bu saldırılar sonucu 10'u polis ve 1'i asker olmak üzere 304 kişinin hayatını kaybettiği, 62'si polis ve 7'si asker olmak üzere 1338 kişinin yaralandığı belirtilmiştir. Buna göre, DEAŞ ile mücadele kapsamında 12 dernek kapatılmış, 2564 sosyal medya hesabına yönelik işlem yapılmıştır, 9 bin 350 
yabancı terörist savaşçı gözaltına alınmış, 1337'si yabancı uyruklu 3069 kişi tutuklanmıştır. Risk analiz birimlerince 17500 yabancı şüpheli kontrol edilirken, bunlardan 4550'si sınır dışı edilmiştir. Çatışma bölgelerine gitmeye çalışan 99 ülkeden 4957 kişiye yönelik sınır dışı kararı uygulanırken, 146 ülkeden 53781 kişiye giriş yasağı konulmuştur. Bunların yanı sıra aralarında canlı bomba saldırısının da olduğu 22 eylem engellenmiştir.

Türkiye'de ayrıca sosyal medyada terör propagandasını engellemek ve sanal ortamda organize suçlarla mücadele etmek maksadıyla İçişleri Bakanlığına bağlı Emniyet Genel Müdürlüğü bünyesinde Siber İstihbarat Şubesi kurulmuştur. Sosyal medyada terör propagandası yapan ve terör faaliyetlerini destekleyen kişiler içinde Emniyet Genel Müdürlügüü tarafından siber@egm.gov.tr, siber.onleme.arastirma@egm.gov.tr, siber.ankara@egm.gov.tr ve siber.istanbul@eg m.gov.tr adresleri üzerinden şikayet hattı oluşturulmuştur. Bunların yanı sıra Facebook, Twitter, YouTube, Instagram ve WhatsApp gibi sosyal ağların kullanım şartları oluşturularak terör propagandası için önlemler alınmaktadır.

Bu çalışmaların yanı sıra Diyanet İşleri Başkanlığı da terör örgütü DEAŞ'a yönelik "Dini İstismar ve Tedhiş Hareketi DEAŞ" (2016: 1-44) başlıklı rapor hazırlayarak DEAŞ benzeri örgütler ile köklü mücadelede yalnızca güvenlik tedbirlerinin yeterli olamayacağını ifade etmektedir. Raporda, örgütün dini bilgi anlayışı, itikadi kavramlara bakışı, örgütün fıkhı kavramları çarptırması ve DEAŞ’tan zarar gören kitleler ayrıntılı şekilde ele alınarak değerlendirilmiştir. Raporda DEAŞ'ın hilafet devleti iddiası, cihat kavramını kirletmesi, şehitlik makamının itibarını zedelemesi, İslami bedeni cezalara indirgemesi ve hür insanların köleleştirilmesi gibi yanlışlarına dikkat çekilmektedir.

\section{SONUÇ}

Yapılan incelemeler sonucunda DEAŞ terör örgütünün etkili propaganda faaliyetlerini sınıflandırmak mümkündür. Buna göre DEAŞ seviyesine göre; taktik, konusunu göre; dinsel, yöntemine göre; korkutucu-yıldırıcı, amacına göre; propaganda, hedef topluma göre; yıkıc1- bölücü ve ikna edici, kapsamına göre; genel, düzlemine göre; yatay ve dikey propaganda faaliyeti yürütmektedir. Bunların yanı sıra 
silahlı propaganda faaliyetlerine sıklıkla başvurduğu görülürken kaynağına göre beyaz ve kara propaganda yapmaktadır.

DEAŞ terör örgütü interneti genelde tanıtım ve propaganda, psikolojik savaş, istihdam ve seferberlik, planlama ve koordinasyon için kullanmaktadır. Örgütün propaganda mesajları incelendiğinde sözde cihat merkezli olduğu, eleman temini ve finansal kaynak sağlamak maksadıyla iletişim kurduğu net bir şekilde görülmektedir.

DEAŞ terör örgütü ile mücadele, yalnızca silahlı şekilde sahada gerçekleştirilecek kadar basit bir olgu değildir. Terör örgütleri ile mücadele için örgütün dijital propaganda faaliyetlerinin sonlandırılması gerekmektedir. Uluslararası sosyal ağlar ve internet siteleri terör propagandası için yeni bir takip sistemi geliştirmeli ve devletlerden gelen müdahale taleplerini anında yerine getirmelidir. Terör örgütlerinin propagandasına yönelik planlı ve sistematik karşı propaganda faaliyetleri gerçekleştirilerek insanların doğru bilgileri edinmeleri ve terör örgütlerine katılımları engellenmelidir. Bunların yanı sıra medya okuryazarlığı ders müfredatları güncellenmeli, dijital propaganda konusu dahil edilerek gençlerde terör propagandasına karşı farkındalık oluşturulmalıdır. Ayrıca din temelli terör örgütlerinin anlamını çarpıtarak kullandıkları dini kavramlar yetkili kurumlarca açıklanmalı, insanlar doğru bilgiye rahatlıkla ulaşabilmeli, resmi kurumlarca verilen din eğitimleri yaygınlaştırılmalı ve güçlendirilmelidir. Bu konuda Diyanet İşıeri Başkanlığına büyük bir görev düşmektedir.

Batılı siyasilerin ve medyanın DEAŞ gibi terör örgütleri üzerinden İslam dinine yönelik olumsuz sözleri ve özellikle İslam ile terörü bir gören yaklaşımları engellenmelidir. Kullanılan "İslami terör", "İslamcı terörist" gibi söylemler Müslümanları kızdırmakta, radikal eğilimi olanları DEAŞ gibi örgütlere yaklaştırmaktadır. Özellikle Türkiye'de "cihat" kavramı DEAŞ söz konusu olduğunda "sözde" tanımlaması ile birlikte kullanılmalıdır. Aynı durum "İslam", "İslami", "İslam Devleti" ve "İslam Medyası" kavramları içinde geçerlidir. 


\section{KAYNAKÇA}

ARSLAN, Ali (2005). "Türkiye'de Medya-Toplum İlişkisi ve Medyanın Profesyonellik Etiği Üzerine Sosyolojik Bir Değerlendirme", Akademik Bakış Uluslararası Sosyal Bilimler E-Dergisi, 5, s.1-13.

AKSOY, Temel (2017). "Propaganda Teknikleri”, http://www.temelaksoy.com/propaganda-teknikleri-nelerdir, Erişim Tarihi: 03.07.2017.

ATABEK, Nejdet (2003). "Propaganda ve Toplumsal Kontrol", Selçuk İletişim Dergisi, 4 (2), s.4-12.

BAŞDOĞAN, Ferhat (1960). Propaganda, Ankara: Kara Kuvvetleri Komutanlığ Yayınlar1.

BEKTAŞ, Arsev (1996). Kamuoyu İletişim ve Demokrasi, İstanbul: Bağlam Yayınları.

BİLGİN, Nuri (2017). "Ermeni Soykırım İddiaları ve Tarihin İnşası", http://www.dagarcikturkiye.com/dosyalar/dosyayonetici/dosya/01012012002 549.pdf., Erişim Tarihi: 26.04.2017.

BOTT, Catherine; DICKENS, Robertson; LARK, Rosemary; THOMPSON, George (2017). "The Internet As A Terrorist Tool For Recruitment \& Radicalization Of Youth", http://barakaconsult.com/uploads/reports\%20on\%20internet_radicalization.pd f., Erişim Tarihi: 15.07.2017.

ÇETIN, Beyzade, Nadir (2014). "Propaganda Olgusu ve Propagandanın Amerikanlaşması", Fırat Üniversitesi Sosyal Bilimler Dergisi, 24 (2), s.239265.

DIYYANET İŞLERİ BAŞKANLIĞI (2016). Din İşleri Yüksek Kurulu Başkanlığg "Dini İstismar ve Tedhiş Hareketi DEAŞ", Ankara: TDV.

DOĞU, Ali Haydar (2016). Bilişim Hukuku, Bursa: Ekin Yayınevi.

DOĞU, Ali Haydar (2016). "Sosyal Medya Paylaşımlarının Hukuki Yönü", Türkiye Bilişim Derneği 33. Ulusal Bilişim Kurultayı Bildiri Kitabı, 8-9 Aralık 2016, Ankara: TBD Yayını, E Kitap.

DOMENACH, J. M. (2003). Politika ve Propaganda, İstanbul: Varlık Yayınları. 
DUHAIME, Christine, (2015). "The Twitter Terrorist: The Islamic State \& the Age of the Digital Terrorist \& Digital Terrorist Financing", http://www.duhaimelaw.com/wp-content/uploads/2015/05/White-Paper.pdf., Erişim Tarihi: 19.06.2017.

FENDOGLU, Hasan, Tahsin (2017). "Terör ve Medya", https://goo.gl/PVf7Xn,Erişim Tarihi: 19.05.2017.

GEÇİKLİ, Fatma (1999)."Geçmişten Günümüze Propaganda Kavramı", İstanbul Üniversitesi İletişim Fakültesi Dergisi, 9, s. 265-276.

GÜNGÖRMEZ, Bengül (2002). "Kitle İletişim Araçları, Siyaset ve Propaganda", Uludağ Üniversitesi Fen-Edebiyat Fakültesi Sosyal Bilimler Dergisi, s. 1-12.

HERMAN, Edward S.; CHOMSKY, Noam (2012). Rızanın İmalatı: Kitle Medyasının Ekonomi Politiği, İstanbul: BGST Yayınları.

HOFFMAN, Adam (2016). "The Islamic State's Use of Social Media: Terrorism's Siren Song in the Digital Age", (Editörler) Yoram Schweitzer and Omer Einav, The Islamic State: How Viable Is It?, Ramat Aviv: INSS, s. 99-105.

HOMEOFFICE (2017). "How Social Media Is Used To Encourage Travel To Syria And Iraq Briefıng Note For Schools", https://goo.gl/wk4Prv, Erişim Tarihi: 27.05.2017.

İÇIŞLERİ BAKANLIĞI (2017). Türkiye'nin DEAŞ ile Mücadelesi, Ankara: Bakanlık Yayını

JOWETT, G.S.; O’DONNEL V. (2012). Propaganda and Persuasion, California: Sage Publications.

KARAARSLAN, Abdulkadir (2014). "İfade Özgürlüğü Bağlamında Terör Propagandasının Yasaklanması Sorunu", Uyuşmazlık Mahkemesi Dergisi, 4, s. 311-349.

KAYABALI, İsmail; ARSLANOĞLU, Cemender (1983). Propagandanın SosyoPsikolojik Temelleri, Ankara: Ongun Kardeşler Matbaacılık.

KER, Müjde (1998). "Halkla İlişkiler ve Propaganda İlişkisi", İstanbul Üniversitesi İletişim Fakültesi Dergisi, 8, s. 265-284.

KESKİNKAYA, Esma (2015). Irak ve Şam İslam Devleti'nin Yeni Medya Kullanımı, Ankara Üniversitesi Sosyal Bilimler Enstitüsü Yayınlanmamış Yüksek Lisans Tezi, Ankara. 
KOÇ, Serhat (2013). Hukuksal Bağlamda Sosyal Medya Analizi ve Kıyaslamalı Mevzuat Önerileri, İstanbul Bilgi Üniversitesi Sosyal Bilimler Enstitüsü Yayınlanmamış Yüksek Lisans Tezi, İstanbul.

KÖSEOĞLU, Yakup; AL, Hamza (2013). "Bir Siyasal Propaganda Aracı Olarak Sosyal Medya", Akademik İncelemeler Dergisi, 8 (3), s.103-125.

LASSWELL, D. Harold (1938). Propaganda Technique World War, New York: Peter Smith.

LERMAN, Kristina (2017). "Social Information Processing in News Aggregation", https://pdfs.semanticscholar.org/2112/386f02791ff2074a33a341dd1e523d6e6 a97.pdf., Erişim Tarihi: 22.06.2017.

MAYFIELD, Antony

(2017).

http://www.icrossing.com/uk/sites/default/files_uk/insight_pdf_files/What\%2 0is\%20Social\%20Media_iCrossing_ebook.pdf., Erişim Tarihi: 14.07.2017)

MEVZUAT BİLGİ SİSTEMİ (2017). "Terörle Mücadele Kanun", http://www.mevzuat.gov.tr/MevzuatMetin/1.5.3713.pdf., Erişim Tarihi: 01.03.2017.

MEVZUAT BİLGİ SİSTEMİ (2017). "İnternet Ortamında Yapılan Yayınların Düzenlenmesi ve Bu Yayınlar Yoluyla İşlenen Suçlarla Mücadele Edilmesi Hakkında Kanun", http://www.mevzuat.gov.tr/MevzuatMetin/1.5.5651.pdf.,Erişim Tarihi: 02.03.2017.

OKTAY, Şahin (2017). "Sosyal Medyada Terör Örgütü Propagandasına Hapis Cezası", http://aa.com.tr/tr/turkiye/sosyal-medyada-teror-orgutupropagandasina-hapis-cezasi/780973, Erişim Tarihi: 28.03.2017.

ORSAM (2016). "Terör Örgütleri Tarafından Sosyal Medyanın Kullanılması: IŞİD Örneği Konferans1", http://www.orsam.org.tr/files/T_Degerlendirme/10/10tr.pdf., $\quad$ Erişim Tarihi:18.01.2017.

ÖZDAĞ, Ümit (2015). Alg1 Yönetimi: Propaganda, Psikolojik Savaş Örtülü Operasyon ve Enformasyon Savaşı, Ankara: Kripto Yayınları. 
PURDY, Walter (2017). "Radicalization: Social Media and the Rise of Terrorism", Homeland Security Digital Library, https://www.hsdl.org/?view\&did=789039 ss.12-16., Erişim Tarihi: 28.05.2017.

QUALTER, Terence H. (2017). Propaganda Teorisi ve Propagandanın Gelişimi", (Çev: Ünsal Oksay), https://goo.gl/EAbXDf, Erişim Tarihi: 28.03.2017.

ROSS, Daveed Gartenstein (2017). "Radicalization: Social Media and the Rise of Terrorism", Homeland Security Digital Library, https://www.hsdl.org/?view\&did=789039, ss.18-33, Erişim Tarihi: 28.05.2017.

SALTMAN E.M.; WINTER C. (2014). "Islamic State: The Changing Face of Modern Jihadism, Quilliam Foundation", http://www.quilliamfoundation.org/wp/wpcontent/uploads/publications/free/islamic-state-the-changing-face-of-modernjihadism.pdf., Erişim Tarihi: 12.01.2017.

SARI, İbrahim (2016). Büyük Fikir Adamı Ziya Gökalp, İstanbul: Nokta E-Kitap.

TANERİ, Gökhan (2016). "Sosyal Medyada Paylaşım Sorumluluğu", TAAD, 24, s. 433-460.

TARHAN, Nevzat (2003). Psikolojik Savaş, İstanbul: Timaş Yayınları.

TEKEL, Suna (2017). "Birleşmiş Milletler ve Uluslararası Terörizm", http://www.ayk.gov.tr/wp-content/uploads, pdf., Erişim Tarihi: 08.06.2017.

TELLİ, Azime (2012). "Misır Devrimi’nde Sosyal Medyanın Rolü", Bilge Strateji Dergisi, 4 (7), s. 65-91.

TÜİK (2017). Adrese Dayalı Nüfus Kayıtları, https://goo.gl/dThpuf,Erişim Tarihi: 15.04.2017.

TÜİK (2017). Bilişim Teknolojileri Araştırması 2016, https://goo.gl/Qj105c,Erişim Tarihi: 15.04.2017.

TÜİK (2017). İnternet Abone Sayısı, https://goo.gl/3m9hJx, Erişim Tarihi: 15.04.2017.

TÜRK DİL KURUMU (2017), "Propaganda", https://goo.gl/FH2fvZ, Erişim Tarihi: 07.06.2017.

We Are Social (2016). Dijital in 2016, https://wearesocial.com/special-reports/digitalin-2016, Erişim Tarihi: 28.01.2017. 
WEIMANN, Gabriel (2017). "How Modern Terrorism Uses the Internet", Washington DC: United States Institute of Peace, Special Report, 116, www.usip.org, Erişim Tarihi: 10.06.2017.

WEIMANN, Gabriel (2014). "New Terrorism and New Media", Washington DC: Commons Lab of the Woodrow Wilson International Center for Scholars.

YARGITAY (2017). Yargıtay İlamı, https://goo.gl/c7S5A8, Erişim Tarihi: 01.08.2017.

YURTLU, Fatih (2016). "Suç Örgütünün Propagandasını Yapma Suçu ve Türkiye Açısından AİHM Kararlarına Yansıması", Gazi Üniversitesi Hukuk Fakültesi Dergisi, 20 (3), s. 411- 435.

YÜKSEL, H. AHMET (2014). İkna Kavramı, (Editör), Mine Oyman. İkna Edici İletişim, Eskişehir: Anadolu Üniversitesi Yayını, s. 2-19. 